\title{
PENINGKATAN MOTIVASI BELAJAR IPS MELALUI MODEL PEMBELAJARAN MIND MAPPING PADA SISWA KELAS IV SDN 106161 LAUT DENDANG
}

\author{
Vivi Uvaira Hasibuan \\ Dosen Prodi Pendidikan Guru Sekolah Dasar STKIP Citra Bangsa Aceh Utara
}

\begin{abstract}
This study aims to determine the increase in student learning motivation in IPS learning using Mind Mapping learning model. This type of research is PTK (classroom action research). The subject of the recipients of the action is the fourth grade students of SDN 106161 Laut Dendang which amounted to 30 students. Methods of data collection is done through questionnaire, observation, and documentation. Technique of data analysis is done by descriptive qualitative which indicate an increase of student's learning motivation in IPS learning on subject of technological development. The results showed that in the first cycle of meeting I the result of student observation 13,56 whereas in cycle I meeting II 16,63 average score of cycle I 15,1 and the average of the whole cycle I 47,16\%. The result of the research on the second cycle of meeting I was the result of student observation 24,43 whereas in second cycle of second meeting 27,85, the average score of cycle I was 26,01 and the average was $81,26 \%$. This research concludes that Mind Mapping learning model in IPS learning can improve student's motivation so that it impact on the improvement of learning achievement.
\end{abstract}

Keywords: motivation, learning, Mind Mapping.

\begin{abstract}
Abstrak: Penelitian ini betujuan untuk mengetahui peningkatan motivasi belajar siswa dalam pembelajaran IPS dengan menggunakan model pembelajaran Mind Mapping. Jenis penelitian ini adalah PTK (penelitian tindakan kelas). Subyek penerima tindakan adalah siswa kelas IV SDN 106161 Laut Dendang yang berjumlah 30 siswa. Metode pengumpulan data dilakukan melalui angket, observasi, dan dokumentasi. Teknik analisis data dilakukan secara deskriptif kualitatif yang menunjukkan adanya peningkatan motivasi belajar siswa dalam pembelajaran IPS pada pokok bahasan perkembangan teknologi. Hasil penelitian menunjukkan pada siklus I pertemuan I hasil observasi siswa 13,56 sedangkan pada siklus I pertemuan II 16,63 rata - rata skor siklus I 15,1 dan rata -rata keseluruhannya siklus I 47,16 \%. Hasil penelitian pada siklus II pertemuan I hasil observasi siswa 24,43 sedangkan pada siklus II pertemuan ke II 27,85, rata - rata skor siklus I 26,01 dan rata -rata keseluruhannya $81,26 \%$. Penelitian ini menyimpulkan bahwa model pembelajaran Mind Mapping dalam pembelajaran IPS dapat meningkatkan motivasi siswa sehingga berdampak pada peningkatan prestasi belajar.
\end{abstract}

Kata kunci: motivasi, pembelajaran, Mind Mapping

\section{PENDAHULUAN}

Berkembangnya ilmu pengetahuan dan teknologi (IPTEK) membawa perubahan gaya hidup manusia yang di tuntut memiliki ilmu serta wawasan yang luas dan mampu memahami teknologi yang berkembang agar memiliki SDM yang berkualitas sehingga menyebabkan sumber daya manusia itu sangat dibutuhkan.Salah satu untuk meningkatkan mutu sumber daya manusia itu adalah dengan meningkatkan mutu pendidikan.

Pendidikan adalah usaha sadar dan terencana untuk mewujudkan suasana belajar dan proses pembelajaran agar peserta didik secara aktif mengembangkan potensi dirinya untuk memiliki kekuatan spiritual keagamaan, pengendalian diri, kepribadian, kecerdasan, akhlak mulia, serta keterampilan yang diperlukan dirinya,masyarakat bangsa dan negara. Ada dua konsep pendidikan yang saling berkaitan yaitu belajar (Learning) dan pembelajaran (Instruction). Konsep belajar berakar pada pihak pendidik. Tujuan pendidikan adalah membentuk sumber daya manusia yang berkualitas tinggi yaitu manusia yang mampu menghadapai perkembangan zaman.

Prestasi belajar merupakan tolok ukur yang utama untuk mengetahui keberhasilan belajar 
seseorang. Seorang yang prestasinya tinggi dapat dikatakan bahwa ia telah berhasil dalam belajar. Menurut Nasution dalam Wartiningsih (2010: 12) Prestasi belajar adalah Penguasaan seseorang terhadap pengetahuan dan ketrampilan tertentu dalam suatu mata pelajaranyang lazimnya diperoleh dari nilai tes/angka yang diberikan guru.

Hasil belajar yang dicapai siswa dapat dipengaruhi oleh dua faktor yaitu faktor internal dan eksternal (Slameto, 2003: 54). Penyebab utama kesulitan belajar (Learning disabilities) adalah faktor internal yaitu diantaranya minat, bakat, motivasi, tingkat intelegensi, sedangkan penyebab utama problema belajar (learning problems) adalah faktor eksternal antara lain berupa strategi pembelajaran yang keliru, pengelolaan kegiatan belajar yang tidak membangkitkan motivasi belajar anak, maupun faktor lingkungan yang sangat berpengaruh pada prestasi belajar yang dicapai oleh siswa.

Salah satu faktor dari dalam diri siswa yang menentukan berhasil tidaknya siswa dalam proses belajar mengajar adalah motivasi belajar. Dalam kegiatan belajar, motivasi merupakan keseluruhan daya penggerak di dalam diri siswa yang menimbulkan kegiatan belajar,yang menjamin kelangsungan dari kegiatan belajar. Motivasi belajar adalah merupakan faktor psikis yang bersifat non intelektual. Seorang siswa yang mempunyai intelegensi yang cukup tinggi, bisa gagal karena kurang adanya motivasi dalam belajarnya.

Motivasi mempunyai peranan penting dalam proses belajar mengajar baik bagi guru maupun siswa. Dalam pembelajaran IPS motivasi belajar siswa masih tergolong rendah. Hal tersebut bisa dilihat dari keinginan siswa dalam belajar masih kurang, kegiatan belajar kurang menarik karena siswa cenderung pasif , kurang dilatih berpikir kritis dan kreatif sehingga motivasi belajar siswa masih rendah dan metode yang digunakan guru kurang bervariasi. Perhatian dan kemandirian siswa masih rendah karena siswa hanya bergantung pada apa yang diberikan oleh guru sehingga nilai yang diperoleh siswa tidak mencapai kriteria ketuntasan minimum (KKM) yang ditentukan yaitu 65. Permasalahan yang dihadapi guru berkaitan dengan kurangnya motivasi anak dalam belajar. Hal tersebut perlu diperhatikan kuhususnya guru. Dalam upaya meningkatkan motivasi belajar, guru berkewajiban untuk menciptakan kegiatan pembelajaran yang mampu membangun kongnitif, afektif dan psikomotorik siswa, dan diperlukan juga kecermatan guru untuk memilih model pembelajaran yang cocok untuk semua mata pelajaran khususnya mata pelajaran IPS.

Untuk mengatasi masalah yang telah dikemukakan di atas salah satunya dengan menerapkan strategi pembelajaran untuk meningkatkan motivasi dan hasil belajar peserta didik adalah dengan menggunakan model pembelajaran Mind Mapping. Selain itu, model pembelajaran Mind Mapping dapat menjadi alternatif dalam menciptakan pembelajaran sebagai proses memetakan pikiran untuk menghubungkan konsep-konsep permasalahan tertentu dari cabang-cabang sel saraf membentuk korelasi konsep menuju pada suatu pemahaman dan hasilnya dituangkan langsung di atas kertas dengan animasi yang disukai dan gampang dimengerti oleh pembuatnya. Sehingga tulisan yang dihasilkan merupakan gambaran langsung dari cara kerja koneksi-koneksi di dalam otak.

Adapun kelebihan dari Mind Mapping ialah meningkatkan rasa tanggung jawab siswa dalam pembelajarannya sendiri dan juga pembelajaran orang lain.Siswa tidak hanya mempelajari materi yang diberikan,tetapi mereka juga dapat berimajinasi,berkhayal dan berkreatif dalam pembelajaran yang tidak lari dan tema yang diberikan,sehingga siswa lebih bebas berkarya dan memudahkan mereka mengingat dalam pembelajaran.

Berdasarkan latar belakang diatas peneliti tertarik untuk melakukan penelitian 
tindakan kelas dengan judul " Peningkatan Motivasi Belajar IPS Melalui Model Pembelajaran Mind Mapping Pada Siswa Kelas IV SDN 106161 Laut Dendang”.

\section{KAJIAN PUSTAKA}

\section{Motivasi Belajar}

Kata " motif ", diartikan sebagai kekuatan yang terdapat dalam diri individu,yang menyebabkan individu tersebut bertindak atau berbuat. Motif tidak dapat diamati secara langsung,tetapi dapat diinterprestasikan dalam tingkah lakunya berupa rangsangan,dorongan,atau pembangkit tenaga munculnya suatu tingkah laku tertentu. Berawal dari kata "motif" itu,maka motivasi dapat diartikan sebagai daya penggerak yang telah menjadi aktif pada saat-saat tertentu,terutama bila kebutuhan untuk mencapai tujuan yang sangat dirasakan/mendesak.

Dengan demikian motivasi merupakan dorongan yang terdapat dalam diri seseorang untuk berusaha mengadakan perubahan tingkah laku yang baik dalam memenuhi kebutuhannya. Dorongan ini berada pada diri seseorang yang menggerakkan untuk melakukan sesuatu yang sesuai dengan dorongan dalam dirinya.yang diberikan kepada seseorang untuk mencapai suatu tujuan yang diberikan.

Menurut Maslow '(dalam Hamzah,2007:5)" motivasi adalah proses psikologi yang dapat menjelaskan perilaku seseorang''.Perilaku pada hakikatnya merupakan orientasi pada suatu tujuan.

Menurut Mc.Donald '(2011: 73)" mengatakan motivai adalah perubahan energy dalam diri seseorang yang ditandai dengan munculnya "feeling" dan didahului dengan tanggapan terhadap adanya tujuan.

Sehingga dapat disimpulkan bahwa motivasi itu sebagai sesuatu yang kompleks.Motivasi akan menyebabkan terjadinya suatu perubahan energy yang ada pada diri manusia yang akan bergayut dengan persoalan gejala kejiwaan,perasaan,dan juga emosi,untuk kemudian bertindak atau melakukan sesuatu.Semua ini didorong karena adanya tujuan,kebutuhan atau keinginan.

Menurut Skinner '(2011:9)' mengatakan bahwa belajar merupakan suatu prilaku.Pada saat orang belajar maka responnya menjadi lebih baik.Sebaliknya bila ia tidak belajar maka responnya menurun.Dalam belajar ditemukan adanya beberapa hal sebagai berikut : 1) kesempatan terjadinya peristiwa yang menimbulkan respons siswa 2) respons siswa dan 3) konsekuensi yang berisifat menguatkan respons tersebut.

Maka dapat disimpulkan bahwa belajar merupakan suatu prilaku yang merespon kearah yang lebih baik dan bersifat menguatkan respons tersebut.

Menurut Dimiyati dan.Mudjiono '(2009:42)" menyatakan bahwa terdapat beberapa prinsip belajar,yaitu :

1. perhatian dan motivasi

2. keaktifan siswa dalam belajar

3. keterlibatan langsung / berpengalaman

4. pengulangan dalam belajar

5. tantangan mencapai suatu tujuan

6. operant Conditioning

7. perbedaan individual

Dalam kegiatan belajar harus diciptakan lingkungan yang kondusif,adapun faktor-faktor psikologis yang memiliki peranan penting dan dapat dipandang sebagai cara-cara berfungsinya pikiran siswa dalam hubungannya dengan pemahaman bahan pelajaran,sehingga penguasaan terhadap bahan yang disajikan lebih mudah dan efektif.

Dengan demikian proses belajar-mengajar itu akan berhasil baik,kalau didukung oleh faktor psikologis si pengajar.Dalam hal ini berbagai model klasifikasinya diperlukan dalam kegiatan belajar.Menurut Sadirman "'(2011:39 )" ada dua faktor yang mempengaruhi psikologis belajar,yaitu : faktor intern (dari dalam) dan faktor ekstern ( dari 
luar) diri si subjek belajar.Hal yang mempengaruhi kepada proses pembelajaran meliputi dalam belajar adalah berasal dari faktor intern,yaitu menyangkut faktor fisiologis dan faktor psikologis.

\section{Mind Mapping}

Mind mapping adalah bentuk catatan yang tidak monoton karena mind mapping memadukan fungsi kerja otak secara bersamaan dan saling berkaitan satu sama lain.Sehingga akan terjadi keseimbangan kerja kedua belahan otak.Otak dapat menerima informasi berupa gambar,simbol,dan laiinnya yang berhubungan dengan fungsi kerja otak kanan.

Menurut Andri saleh '(2008:68)" Mind Mapping adalah diagram yang digunakan untuk menggambarkan sebuah tema,ide,atau gagasan utama dalam materi pembelajaran.Tema,ide,atau gagasan utama ditempatkan di tengah-tengah diagram.Masingmasing tema,ideatau gagasan utama tersebut membentuk jaringan yang sangat luas.Jaringan-jaringan dibuat saling berkaitan satu dengan yang lainnya.

Dengan demikian Mind Mapping adalah gamabaran menyeluruh dari suatu materi pembelajaran yang dibuat dalam bentuk sederhana.Mind mapping membantu siswa untuk menggunakan kedua belahan otak yaitu otak kiri dan otak kanan,menurut pendapat Tony buzan ''( 2007:4 )".

\section{Aplikasi Mind Mapping pada pembelajaran}

Mind mapping sering berkaitan dengan peta konsep,akan tetapi Mind mapping dan peta konsep memiliki perbedaan.Letak perbedaan itu sendiri adalah mind mapping hanya memilki 1 sentral/topic utama.Peta konsep bisa memiliki lebih dari satu topik utama,yang masing-masing dari topic utama tersebut memiliki kaitan satu sama lain.Secara lebih jelas dapat terlihat gambar aplikasi dari mind mapping berikut ini :

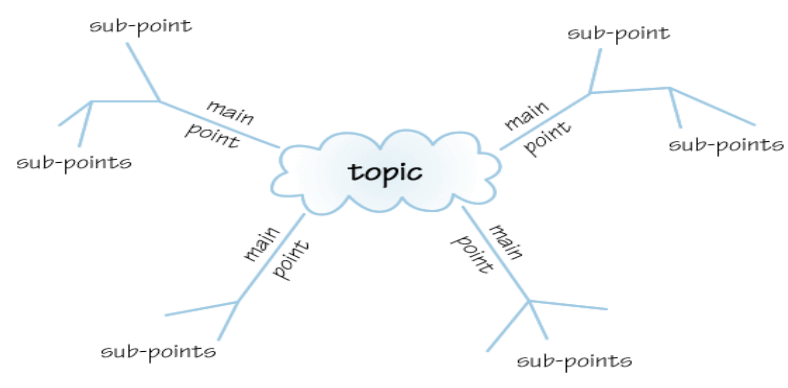

Gambar 1. Aplikasi mind mapping

Dalam tahap aplikasi dari proses pembelajaran Mind Mapping terdapat 4 langkah yang harus dilakukan yaitu :

1. Overview: tinjauan Menyeluruh terhadap suatu topik pada saat proses pembelajaran baru dimulai. Hal ini bertujuan untuk memberi gambaran umum kepada siswa tentang topik yang akan dipelajari.

2. Preview: tinjauan Awal merupakan lanjutan dari Overview sehingga gambaran umum yang diberikan setingkat lebih detail daripada Overview dan dapat berupa penjabaran lebih lanjut dari Silabus atau GBPP. Dengan demikian siswa diharapkan telah memiliki pengetahuan awal yang cukup mengenai subtopik dari bahan sebelum pembahasan yang lebih detail dimulai

3. Inview: tinjauan Mendalam yang merupakan inti dari suatu proses pembelajaran dimana suatu topik akan dibahas secara detail, terperinci dan mendalam. Selama Inview ini siswa diharapkan dapat mencatat informasi, konsep atau rumus penting beserta grafik, daftar atau diagram untuk membantu siswa dalam memahami dan menguasai bahan yang diajarkan.

4. Review: tinjauan Ulang dilakukan menjelang berakhirnya jam pelajaran dan berupa ringkasan dari yang bahan telah diajarkan serta ditekankan pada informasi, konsep atau rumus penting yang harus diingat atau dikuasai oleh siswa. Hal ini akan dapat membantu siswa untuk fokus dalam mempelajari-ulang seluruh bahan yang diajarkan di sekolah pada saat di rumah. 
Review dapat juga dilakukan saat pelajaran akan dimulai pada pertemuan berikutnya untuk membantu siswa mengingatkan kembali bahan yang telah diajarkan pada pertemuan sebelumnya.

\section{METODE PENELITIAN}

Jenis penelitian ini adalah Penelitian Tindakan Kelas (PTK). Sesuai dengan jenis penelitian ini maka penelitian melakukan tahap - tahap penelitian yang berupa dua siklus yang bertujuan untuk memperbaiki proses pembelajaran dan meningkatkan motivasi belajar siswa dengan menggunakan model pembelajaran Mind Mapping Pada pembelajaran IPS pokok bahasan perkembangan teknologi.

Metode pengumpulan data dilakukan melalui angket, observasi, dan dokumentasi. Teknik analisis data dilakukan secara deskriptif kualitatif . Subjek dalam penelitian ini adalah seluruh siswa kelas IV SD Negeri 106161 Laut Dendang sebanyak 30 siswa, yang terdiri dari 16 siswa laki-laki dan 14 siswa perempuan. Sedangkan objek dalam penelitian ini adalah upaya peningkatan motivasi belajar siswa dalam pembelajaran IPS.

\section{HASIL PEMBAHASAN}

\section{Hasil Pengujian Hipotesis}

Sebelum melakukan tindakan motivasi belajar siswa masih rendah dan untuk meningkatkan motivasi belajar siswa,peneliti memilih model Mind Mapping sebagai strategi untuk menyampaikan pelajaran.

Berdasarkan hasil pengamtan masih terdapat beberpa siswa yang kurang termotivasi. Berdasarkan keterangan tersebut dapat disimpulkan bahwa terdapat peningkatan motivasi siswa mulai dari siklus I sampai pada siklus II.

Berdasarkan hasil penelitian tersebut terbukti bahwa penggunaan model Mind Mapping pada materi perkembangan teknologi dapat mempermudah pemahaman siswa.

Tabel 1. Hasil Skor Motivasi pada Siklus I dan Siklus II

\begin{tabular}{|c|c|c|c|c|c|l|}
\hline \multirow{2}{*}{ No } & \multirow{2}{*}{$\begin{array}{c}\text { No.U } \\
\text { rut } \\
\text { Siswa }\end{array}$} & Skor & Siklus & \multicolumn{2}{|c|}{ Siklus II } & \\
\cline { 3 - 6 } & & & Skor & \% & Keterangan \\
\hline 1 & 1 & 9 & 28,1 & 26,5 & 82,8 & Meningkat \\
\hline 2 & 2 & 10 & 31,2 & 27 & 84,4 & Meningkat \\
\hline 3 & 3 & 26 & 81,2 & 29 & 90,6 & Meningkat \\
\hline 4 & 4 & 20 & 62,5 & 26 & 81,2 & Meningkat \\
\hline 5 & 5 & 15,5 & 48,4 & 26,5 & 82,8 & Meningkat \\
\hline 6 & 6 & 11 & 34,3 & 24 & 75 & Meningkat \\
\hline 7 & 7 & 9 & 28,1 & 26 & 81,2 & Meningkat \\
\hline 8 & 8 & 12,5 & 39,1 & 26 & 81,2 & Meningkat \\
\hline 9 & 9 & 13 & 40,6 & 22 & 68,7 & Meningkat \\
\hline 10 & 10 & 12 & 37,5 & 20 & 62,5 & Meningkat \\
\hline 11 & 11 & 9 & 28,1 & 26,5 & 82,8 & Meningkat \\
\hline 12 & 12 & 19,5 & 60,9 & 26,5 & 82,8 & Meningkat \\
\hline 13 & 13 & 14 & 43,7 & 27,5 & 85,9 & Meningkat \\
\hline 14 & 14 & 27 & 84,3 & 30,5 & 95,3 & Meningkat \\
\hline 15 & 15 & 12 & 37,5 & 26,5 & 82,8 & Meningkat \\
\hline 16 & 16 & 20 & 62,5 & 28 & 87,5 & Meningkat \\
\hline 17 & 17 & 19 & 59,3 & 24 & 75 & Meningkat \\
\hline 18 & 18 & 20,5 & 64,1 & 27 & 84,3 & Meningkat \\
\hline 19 & 19 & 26 & 81,2 & 29 & 90,6 & Meningkat \\
\hline 20 & 20 & 12 & 37,5 & 26 & 81,2 & Meningkat \\
\hline 21 & 21 & 11 & 34,3 & 26 & 81,2 & Meningkat \\
\hline 22 & 22 & 9 & 28,1 & 26 & 81,2 & Meningkat \\
\hline 23 & 23 & 12 & 37,5 & 26,5 & 82,8 & Meningkat \\
\hline 24 & 24 & 14 & 43,7 & 26,5 & 82,8 & Meningkat \\
\hline 25 & 25 & 12,5 & 39,1 & 27 & 84,4 & Meningkat \\
\hline 26 & 26 & 15,5 & 48,4 & 20 & 62,5 & Meningkat \\
\hline 27 & 27 & 20 & 62,5 & 26 & 81,2 & Meningkat \\
\hline 28 & 28 & 10 & 31,2 & 26,5 & 82,8 & Meningkat \\
\hline 29 & 29 & 12 & 37,5 & 27,5 & 85,9 & Meningkat \\
\hline 30 & 30 & 20 & 62,5 & 24 & 75 & Meningkat \\
\hline Jumlah & 453 & 141 & 780,5 & 243 & \\
\hline Ratan & & & 4,9 & 8 & \\
\hline & & 15,1 & 47,1 & 26,01 & 81,2 & \\
\hline
\end{tabular}


Berdasarkan skor keseluruhan dari siklus I ke siklus II maka hasil perubahan dapat dilihat rekapitulasinya pada tabel berikut ini :

Tabel II . Rekapitulasi Perubahan Tingkat Motivasi Belajar Siswa

\section{Siklus I ke Siklus II}

\begin{tabular}{|c|c|c|c|c|c|}
\hline \multirow{2}{*}{ No } & Keterangan & \multicolumn{2}{|c|}{ Siklus I } & \multicolumn{2}{c|}{ Siklus II } \\
\cline { 3 - 6 } & & Jumlah & \% & Jumlah & \% \\
\hline 1 & Rendah & 18 & 60 & 0 & 0 \\
\hline 2 & Sedang & 9 & 30 & 6 & 20 \\
\hline 3 & Tinggi & 3 & 10 & 24 & 80 \\
\hline
\end{tabular}

Untuk lebih jelasnya lihat grafik perubahan tingkat motivasi belajar siswa IPS kelas IV SDN 106161 Laut Dendang dengan model pembelajaran Mind Mapping.

Grafik 1. Perubahan Tingkat Motivasi Siswa dari Siklus I ke Siklus II

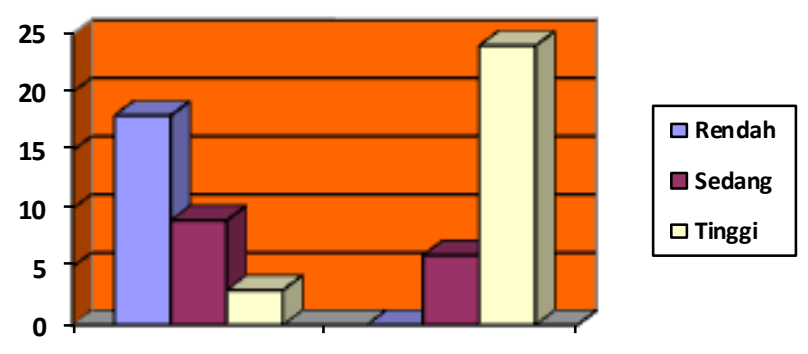

Berdasarkan grafik 1 diatas dapat diketahui bahwa terjadi perubahan motivasi belajar mulai dari siklus I dan siklus II di kelas IV SDN 106161 Laut Dendang, hal ini dapat dilihat dari :

1. Dari 30 orang siswa di atas pada siklus I ada sebanyak 18 orang siswa atau 60 $\%$,pada siklus II ada sebanyak 0 orang siswa atau $0 \%$ yang tergolong criteria motivasi rendah.

2. Dari 30 orang siswa di atas pada siklus I ada sebanyak 9 orang siswa atau 30 $\%$,pada siklus II ada sebanyak 6 orang siswa atau $20 \%$ yang tergolong criteria sedang pp. $45-51$

3. Dari 30 orang siswa diatas pada siklus I ada sebanyak 3 orang siswa atau 10 $\%$,pada siklus II ada sebanyak 24 orang siswa atau $80 \%$ yang tergolong criteria motivasi tinggi.

Dengan model Mind Mapping ternyata dapat meningkatkan motivasi belajar siswa pada pelajaran IPS di kelas IV SDN Laut Dendang. Hal ini terlihat dari setiap jumlah nilai siswa meningkat secara signifikan.

\section{SIMPULAN DAN SARAN}

\section{Simpulan}

Berdasarkan hasil penelitian yang telah disajikan dalam bab IV maka dapat disimpulkan bahwa :

Pembelajaran dengan menggunakan model pembelajaran Mind Mapping dapat meningkatkan motivasi belajar siswa dalam pembelajaran IPS khususnya pada materi pokok perkembangan teknologi di kelas IV SDN 106161 Laut Dendang.

Dapat meningkatkan motivasi belajar siswa. Hal ini dapat dilihat adanya peningkatan pada 8 indikator yaitu : (1) Keterampilan membuka pelajaran (2) Menjelaskan model Mind Mapping yang digunakan (3) Menjelaskan materi dengan mind mapping secara sistematis(4) Membuat pokok pembahasan sebagai pusat Mind Mapping (5). Memotivasi siswa dalam membuat rangkuman pelajaran dengan menggunakan model Mind Mapping(6) Membimbing siswa dalam membuat rangkuman pelajaran dengan menggunakan model Mind Mapping (7). Keterampilan menutup pelajaran (8). Memberikan tugas (PR) kepada siswa secara mandiri

Dengan menggunakan model mind mapping meningkatkan kualitas proses pembelajaran yang dilakukan guru dan mencapai motivasi belajar siswa. 
Siswa sangat antusias dalam mengikuti pembelajaran dengan menggunakan model mind mapping. Hal ini dapat dilihat dari rata rata kelas belajar yang diajarkan dengan menggunakan model mind mind mapping lebih baik dari sebelumnya.

Adapun peningkatan motivasi skor rata - rata siswa adalah sebagai berikut, secara Siklus I, Pertemuan I dan II, 15,1 \% dan 47,16 $\%$. Siklus II, Pertemuan I dan II $26,01 \%$ dan $81,26 \%$

\section{Saran}

Dalam kegiatan belajar mengajar siswa hendaknya turut aktif dalam belajar. Apabila siswa merasa bosan dengan pembelajaran hendaknya siswa meminta guru agar mengganti model pengajarannya. Guru haruslah selalu memiliki ide - ide baru dalam meningkatkan mutu pembelajaran dalam proses belajar mengajar. Guru juga harus jeli melihat apa - apa saja yang mendukung proses pembelajaran dikelas sehingga siswa selalu rindu untuk belajar. Satu hal yang paling penting, guru harus mengembangkan penelitian tindakan kelas karena sangat berguna untuk meningkatkan keterampilan guru dalam memecahkan masalah dikelas. Sehingga akan terciptanya suasana kegiatan belajar mengajar yang menyenangkan bagi siswa. Penelitiaan tindakan kelas hendaknya digunakan oleh sekolah - sekolah sebagai salah satu cara untuk menyelesaikan permasalahan terutama yang berkaitan dengan masalah motivasi dan hasil belajar. Penelitiaan tindakan kelas mampu mengidentifikasi dan menindaklanjuti suatu permasalahan yang berkaitan dengan proses belajar mengajar di kelas. Selain itu, penelitian tindakan kelas juga dapat digunakan sebagai alat control kinerja guru dalam mengajar sehingga kompetensi guru akan semakin baik.

\section{DAFTAR PUSTAKA}

Arikunto ,Suharsimi, dkk. (2008).Penelitian Tindakan Kelas. Jakarta : Bumi Aksara
7 Pages pp. $45-51$

Buzan,Tony . (2008) Mind Mapping Untuk

Anak. Jakarta : Gramedia Pustaka Utama

Buzan,Tony .(2009). Buku Pintar Mind Mapping. Jakarta : Gramedia Pustaka Utama.

Chaplain (dalam anwar) . 2008. Cara Belajar Yang Efektif. Medan : Bina Aksara

Dewi, Rosmala. (2010). Penelitian Tindakan Kelas.Medan : Program Pascasarjana Unimed.

Dimyati,Mudjiono (2009). Belajar dan Pembelajaran. Jakarta : RINEKA CIPTA.

Hamzah,Uno B.( 2008). Teori Motivasi dan Pengukurannya. Jakarta : Bumi Aksara.

Hamzah,Uno B. (2007). Model Pembelajaran Menciptakan Proses Belajar Mengajar yang Kreatif dan Efektif. Jakarta : Bumi Aksara.

Istarani. (2011) Model Pembelajaran Inovatif. Medan : Media Persada.

Lusinta Afrisanti. (2011). Buku Pintar Menjadi Guru Kreatif,Inspiratif dan Inovatif. Yogyakarta : Araska.

Saleh,Andri. (2008). Kreatif Mengajar Mind Mapping. Bandung : TINTA EMAS Publishing.

Sardiman,AM.(2011). Interaksi \& Motivasi Belajar Mengajar. Jakarta: PT. Rajagrafindo Persada.

Sukardi,ph D. (2003).Metodologi Penelitian Pendidikan. Jakarta : Bumi Aksara 